\title{
Educação popular como instrumento de reorientação das estratégias de controle das doenças infecciosas e parasitárias
}

\author{
Popular education as a tool for redirecting \\ strategies to deal with infectious \\ and parasitic diseases
}

Eymard Mourão Vasconcelos 1

${ }^{1}$ Departamento de Promoção da Saúde, Centro de Ciências da Saúde, Universidade Federal da Paraíba. Cidade Universitária, João Pessoa, $P B$ 58059-900, Brasil. eymard@funape.ufpb.br

\begin{abstract}
There has been a comprehensive debate among different methodological approaches in Primary Health Care Services which inform different types of action to deal with infectious diseases, some of them emphasizing the community involvement in the search for solutions. This study aimed to clarify methodologies for popular education in the health field, specifically those most appropriate for the present institutional context, besides analyzing their meaning in dealing with infectious and parasitic diseases. The study involved a health center on the outskirts of the city of Belo Horizonte, Minas Gerais, Brazil. While working to improve this clinic's educational practices, the author attempted to identify and investigate the difficulties and potentialities in the relationship between health professionals and the population. He also focused on showing how cultural, cognitive, and subjective issues can both hamper and facilitate the health services' functioning, indicating the need for health organizations to deal with such issues in a systematic and clear-cut way. This action-based research thus centers on participant observation, whereby involvement in the problems of malnourished children led to a series of changes in the relationship with the local community.
\end{abstract}

Key words Health Education; Primary Health Care; Communicable Diseases; Public Health

Resumo Tem havido um amplo debate entre diferentes concepções metodológicas que orientam as estratégias de combate às doenças infecciosas e parasitárias nos serviços de atenção primária à saúde, algumas delas enfatizando o envolvimento da população na busca de soluções. Este trabalho se baseia em pesquisa realizada em um centro de saúde da periferia de Belo Horizonte entre 1994 e 1997, com o objetivo de contribuir na explicitação, de forma mais clara, da metodologia de educação popular em saúde adequada ao atual contexto institucional e de analisar o seu significado no combate às doenças infecciosas e parasitárias. Neste centro de saúde, ao se procurar dinamizar as suas práticas educativas, buscou-se identificar e entender os bloqueios e potencialidades existentes no relacionamento entre os profissionais e a população. Procurou-se esclarecer a forma como as questões culturais, cognitivas e subjetivas dificultam e favorecem o funcionamento de um serviço de saúde. Trata-se, portanto, de uma pesquisa-ação com ênfase na observação participante em que o envolvimento com os problemas de saúde de crianças desnutridas foi desencadeando uma série de mudanças no relacionamento do serviço de saúde com a comunidade local.

Palavras-chave Educação em Saúde; Cuidados Primários à Saúde; Doenças Transmissíveis; Saúde Pública 


\section{Introdução}

Diarréia, escabiose, verminoses intestinais, impetigo, micoses cutâneas, doenças venéreas, infecções exantemáticas agudas, resfriados, pediculose, pneumonia, tungíase, faringites e outras doenças infecciosas e parasitárias fazem parte da rotina diária das famílias das classes populares brasileiras. Numa mesma família, costuma-se observar, ao mesmo tempo, várias dessas infecções, que têm caráter extremamente repetitivo. Muitas vezes, um membro da família só é levado a um serviço de saúde quando é ultrapassado determinado nível de tolerância ou quando surge alguma nova condição que facilite o acesso. Nessa convivência diária com as doenças infecciosas corriqueiras, há elementos de sofrimento e desespero, resistência e busca de estratégias de enfrentamento, esgotamento e passividade. Esses elementos se interagem numa dinâmica complexa em razão das condições materiais e sociais a que estas pessoas estão submetidas. Os serviços hospitalares, ambulatoriais e as campanhas de saúde pública interferem apenas pontualmente e ocasionalmente nesta dinâmica. Pouco se tem estudado sobre como as classes populares estão entendendo, elaborando e se apropriando das mensagens e saberes transmitidos nas ações oficiais de saúde.

Uma vez que a ação dos serviços no meio popular é tênue, a superação da situação de intenso adoecimento por doenças infecciosas e parasitárias, encontrada principalmente nos primeiros anos de vida, depende do envolvimento da população na busca de novas estratégias e do reforço às posturas de luta e enfrentamento que sejam cientificamente respaldadas e apropriadas às condições materiais e sociais em que vivem. Depende também da construção e desenvolvimento de serviços e obras públicas adequadas a essas condições. No entanto, a medicina tem concentrado seus esforços no desenvolvimento de técnicas medicamentosas, cirúrgicas e eletrônicas, que atuam no processo saúde-doença apenas no nível do corpo biológico e que são voltadas para o enfrentamento de doenças isoladas. O esforço médico, em geral, corre paralelo, dessincronizado e até em oposição ao esforço popular de combate aos problemas de saúde. Não tem sido uma preocupação importante da Medicina a compreensão dos saberes, das estratégias, dos significados imaginários e das contradições e passividades do meio popular em face das doenças infecciosas e parasitárias usuais, a fim de possibilitar uma crítica aos procedimentos médicos e sanitários tradicionais e a criação de novas formas de abordagem, de modo a caminhar para a integração entre o agir médico e o agir popular. Normalmente se confia no bom senso dos profissionais para a construção dessa integração. Outras vezes se delega esta tarefa a profissionais específicos (visitadoras sanitárias, assistentes sociais etc.), que, atuando de forma paralela e desvinculada da rotina de atendimentos técnicos individuais prestados, terminam não conseguindo uma mudança significativa na globalidade das práticas de enfrentamento das doenças infecciosas e parasitárias.

\section{Atenção primária à saúde e o cotidiano das doenças infecciosas e parasitárias no meio popular}

Com a emergência dos serviços de atenção primária à saúde, estas questões se tornaram fundamentais. Antes, a grande distância entre os hospitais e ambulatórios centrais e o cotidiano da vida popular tornava impossível uma interferência mais significativa nesse nível para os profissionais ali situados. Mas os centros e postos de saúde representam uma inovação institucional justamente porque possibilitam essa aproximação. A experiência internacional, como é o caso cubano, tem demonstrado que a sua surpreendente eficiência se dá na medida em que o serviço consegue se inserir profundamente na dinâmica social local. Nesse sentido, é prioritário superar o fosso existente entre a ação médica e a ação popular na luta contra as doenças infecciosas e parasitárias.

Desde meados da década de 1970, vêm se multiplicando os centros e postos de saúde no Brasil. Apesar de marcados pela carência material e de recursos humanos qualificados, pela sua utilização eleitoreira por parte da classe política e pela falta de eficiência operacional, estes novos serviços estão assumindo uma importância central nas estratégias de combate às doenças infecciosas e parasitárias no Brasil. $\mathrm{O}$ fato de estarem mais profundamente inseridos na dinâmica social local, de terem uma constância e uma continuidade de atuação, de integrarem ações educativas, preventivas e curativas e de serem de fácil acesso à população, proporciona a esses serviços uma grande potencialidade no enfrentamento do quadro de adoecimento e morte, como já foi evidenciado em muitas experiências internacionais e em alguns municípios brasileiros. Com o movimento de Reforma Sanitária e o processo de implantação do Sistema Único de Saúde (SUS), eles tendem a se constituir como o alicerce da as- 
sistência à saúde. As grandes endemias, que vinham sendo enfrentadas com programas especiais implementados por órgãos federais ou estaduais mediante campanhas verticais, vão, aos poucos, passando para a responsabilidade dos municípios, onde os serviços locais de saúde são a maior ferramenta institucional. Mas, como será visto, esta passagem não é tranqüila.

No novo contexto, diferentes concepções e propostas de organização da atenção primária à saúde convivem e divergem entre si. Conseqüentemente, diferentes concepções e propostas de enfrentamento das doenças infecciosas e parasitárias no nível local também convivem e digladiam entre si.

\section{A educação popular em saúde e as doenças infecciosas e parasitárias}

A educação em saúde é o campo de prática e conhecimento do setor saúde que tem se ocupado mais diretamente com a criação de vínculos entre a ação médica e o pensar e fazer cotidiano da população. Mas, até a década de 1970, a educação em saúde no Brasil foi basicamente uma iniciativa das elites políticas e econômicas e, portanto, subordinada aos seus interesses. Voltava-se para a imposição de normas e comportamentos considerados adequados por aquelas elites. Para os grupos populares, que conquistaram maior força política, as ações de educação em saúde foram esvaziadas em favor da expansão da assistência médica individualizada.

O governo militar, imposto pela Revolução de 1964, criou contraditoriamente condições para a emergência de uma série de experiências de educação em saúde que significaram uma ruptura com o padrão acima descrito. Nesta época, a política de saúde se volta para a expansão de serviços médicos privados, principalmente hospitalares, onde as ações educativas não tinham espaço significativo. A tranqüilidade social imposta pela repressão política e militar possibilitou ao regime voltar suas atenções para a expansão da economia, diminuindo os gastos com as políticas sociais. Com os partidos e sindicatos esvaziados, a população vai aos poucos buscando novas formas de resistência. A Igreja Católica, que conseguira se preservar da repressão política, apóia aquele movimento, possibilitando o engajamento de intelectuais das mais diversas áreas. O método da educação popular, sistematizado por Paulo Freire, constitui-se como norteador da relação entre intelectuais e classes populares. Muitos profissionais de saúde, insatisfeitos com as práticas mercantilizadas e rotinizadas dos serviços de saúde, engajam-se naquele processo. Nos subterrâneos da vida política e institucional, vai-se tecendo a estrutura de novas formas de organização da vida política. Essas experiências possibilitam aos intelectuais o acesso à dinâmica de luta e resistência das classes populares e fazem com que comecem a conhecêla. No vazio do descaso do Estado com os problemas populares, vão-se configurando iniciativas de busca de soluções técnicas construídas a partir do diálogo entre o saber popular e o saber acadêmico.

O setor saúde é exemplar neste processo. Nos anos 70, junto aos movimentos sociais emergentes, começam a surgir experiências de serviços comunitários de saúde desvinculados do Estado, onde profissionais de saúde aprendem a se relacionar com os grupos populares, começando a esboçar tentativas de organização de ações de saúde integradas à dinâmica social local. Com o processo de abertura política, movimentos populares, que já tinham avançado na discussão das questões de saúde, passam a reivindicar serviços públicos locais e a exigir participação no controle de serviços já estruturados. A experiência ocorrida na zona leste da cidade de São Paulo é o exemplo mais conhecido, mas o MOPS - Movimento Popular de Saúde - chegou a aglutinar centenas de outras experiências nos diversos estados. Nelas, a educação em saúde busca ser uma assessoria técnica às demandas e iniciativas populares, bem como um instrumento de dinamização das trocas de conhecimento entre os atores envolvidos.

Assim, a participação de profissionais de saúde nas experiências de educação popular a partir dos anos 70 trouxe para o setor saúde uma cultura de relação com as classes populares que representou uma ruptura com a tradição autoritária e normatizadora da educação em saúde.

Com a conquista da democracia política e a construção do Sistema Único de Saúde na década de 1980, essas experiências localizadas de trabalho comunitário em saúde perderam sua importância. Os movimentos sociais passaram a lutar por mudanças mais globais nas políticas sociais. Os técnicos que nelas estiveram engajados agora ocupam espaços institucionais amplos, onde uma convivência direta tão intensa com a população não é mais possível. Mas a experiência de integração vivida por tantos intelectuais e líderes populares, o saber ali construído e os modelos institucionais que começaram a ser gestados continuam presentes. Em muitas instituições de saúde, grupos de 
profissionais têm buscado enfrentar o desafio de incorporar no serviço público a metodologia da educação popular, adaptando-a ao novo contexto de complexidade institucional e da vida social nos grandes centros urbanos. Enfrentam tanto a lógica hegemônica de funcionamento dos serviços de saúde, subordinados aos interesses de legitimação do poder político e econômico dominante, como a carência de recursos oriunda do conflito distributivo no orçamento, numa conjuntura de crise fiscal do Estado. Neste sentido, esses grupos estão engajados na luta pela democratização do Estado, na qual o método da educação popular passa a ser um instrumento para a construção e ampliação da participação popular no gerenciamento e reorientação das políticas públicas.

Uma grande parte das práticas de educação popular nos serviços de saúde está hoje voltada para a superação do fosso cultural existente entre a instituição e a população, pois um lado não compreende a lógica e as atitudes do outro. Nessas experiências isto é feito a partir de uma perspectiva de compromisso com os interesses políticos das classes populares, mas reconhecendo, cada vez mais, a sua diversidade e heterogeneidade. Assim, priorizam a relação com os movimentos sociais locais por serem expressões mais elaboradas destes interesses. Atuando a partir de problemas de saúde específicos ou de questões ligadas ao funcionamento global do serviço, buscam entender, sistematizar e difundir as lógicas, os conhecimentos e os princípios que regem a subjetividade dos vários atores envolvidos, a fim de superar as incompreensões e mal-entendidos ou tornar conscientes e explícitos os conflitos de interesse. Nessas iniciativas de educação popular em saúde se dá uma grande ênfase à estruturação de instrumentos de ampliação dos canais de interação cultural e de negociação (cartilhas, jornais, assembléias, reuniões, cursos, visitas etc.) entre os diversos grupos populares e os diversos tipos de profissionais.

Tendo como base posturas como essa, temse assistido, em alguns locais, à emergência de novos padrões de enfrentamento dos problemas de saúde marcados pela integração entre o saber técnico e o saber popular e pela mútua colaboração. Nesse sentido, a educação em saúde deixa de ser uma atividade a mais realizada nos serviços para ser algo que atinge e reorienta a diversidade de práticas ali realizadas. Passa a ser um instrumento de construção da participação popular nos serviços de saúde e, ao mesmo tempo, de aprofundamento da intervenção da ciência na vida cotidiana das famílias e da sociedade. Apesar de esse processo vir ocorrendo no Brasil de forma fragmentada em experiências e iniciativas marcadas pela transitoriedade, tal constatação coincide com a percepção de autores situados em outros países, como MacDonald \& Warren (1991), da Inglaterra e Austrália, respectivamente: “A educação não é um mero componente da Atenção Primária à Saúde. Antes disto, esta é, em sua totalidade, um processo eminentemente educativo na medida em que, na perspectiva defendida pela Conferência de Alma Ata, se baseia no encorajamento e apoio para que as pessoas e grupos sociais assumam um maior controle sobre sua saúde e suas vidas (...). Grande parte do que Paulo Freire diz sobre o processo educativo é diretamente aplicável à Atenção Primária à Saúde. Nós afirmamos ainda mais: a metodologia educativa de Paulo Freire é uma sólida base para se atingir uma Atenção Primária à Saúde integral" (MacDonald \&Warren, 1991:39-44).

A educação popular não é o único projeto pedagógico a valorizar a diversidade e a heterogeneidade dos grupos sociais, a intercomunicação entre os diferentes atores sociais, o compromisso com as classes subalternas, as iniciativas dos educandos e o diálogo entre o saber popular e o saber científico. Mas, para o setor saúde brasileiro, a participação histórica no movimento da educação popular foi marcante na criação de um movimento de profissionais que busca romper com a tradição autoritária e normatizadora da relação entre os serviços de saúde e a população. Apesar de uma certa crise do conceito de educação popular nos novos tempos, é ele que vem servindo para identificar e instrumentalizar a diversidade de práticas emergentes.

Com a priorização internacional da atenção primária em saúde, tendo como marco a Conferência de Alma-Ata em 1978, os organismos internacionais de saúde, como a Organização Mundial de Saúde (OMS), passaram a enfatizar a necessidade de se estudar o contexto cultural das populações para uma melhor adequação das práticas de saúde. Mas a maioria das orientações e das novas práticas emergentes (Campbell, 1993:2) caracterizam-se por uma utilização instrumental e simplificadora dos dados culturais locais: as crenças, linguagem e iniciativas da população são estudadas para fazer as mensagens educativas se tornarem mais compreensíveis e mais atraentes. As prioridades e os conhecimentos educativos necessários continuam sendo determinados pelo grupo de técnicos sem se deixar questionar pelas razões, interesses e saberes da população, só que agora procurando revesti-los espertamente com discursos locais ou associando-os 
com acontecimentos e crenças daquela população. Apesar da nova roupagem antropológica, continuam repetindo o modelo da educação bancária criticado por Freire (1979:66): “A narração de que o educador é o sujeito, conduz os educandos à memorização mecânica do conteúdo narrado. Mais ainda, a narração os transforma em 'vasilhas', em recipientes a serem 'enchidos' pelo educador. Quanto mais vá 'enchendo' os recipientes com seus 'depósitos', tanto melhor educador será. Quanto mais se deixem docilmente "encher", tanto melhores educandos serão. (....) nesta distorcida visão da educação, não há criatividade, não há transformação, não há saber. Só existe saber na invenção, na reinvenção, na busca inquieta, impaciente, permanente, que os homens fazem no mundo, com o mundo e com os outros".

As práticas de educação em saúde baseadas no repasse de conhecimentos deixam de lado questões importantes. Que parcelas do amplo conhecimento científico acumulado interessam aos setores populares que estão sendo acometidos por determinado problema de saúde? Não seria necessário saber como esses setores constroem seu conhecimento para se chegar a uma seleção dos conhecimentos com os quais se vai trabalhar? Não seria necessário aprender com eles como acontece em detalhes a sua convivência cotidiana com estes problemas para então se perceber que dimensões do conhecimento técnico podem ser úteis? Diante da insuficiência do conhecimento científico para entender a complexidade da vida e propor soluções, não seria necessário valorizar o conhecimento e o saber presentes na cultura popular construído ao longo do processo histórico da humanidade? Diante da diversidade de situações de relacionamento entre os técnicos e a população, que momentos e circunstâncias são propícios ao aprendizado e de que forma os vários conhecimentos são apropriados? O conhecimento da realidade da população é útil apenas na medida em que possibilita encontrar estratégias facilitadoras da transmissão? A questão é simplificar e facilitar a mensagem, ou é buscar a construção de um outro conhecimento que é resultado de uma relação entre as duas partes? (Valla, 1993:93).

A saída metodológica que a educação popular propõe para estas questões é buscar subordinar o ato pedagógico ao movimento dos próprios educandos em direção ao 'ser mais', tentando superar as limitações e opressões de suas vidas. Para isso, o educador deve investir na descoberta e inserção neste movimento (de busca e de construção) existente na dinâmica social do grupo em que atua. "Educação popu- lar não visa criar sujeitos subalternos educados: sujeitos limpos, polidos, alfabetizados, bebendo água fervida, comendo farinha de soja e cagando em fossas sépticas. Visa participar do esforço que já fazem hoje todas as categorias de sujeitos subalternos - do índio ao operário do ABC paulista - para a organização do trabalho político que, passo a passo, abra caminho para a conquista de sua liberdade e de seus direitos. A educação popular é um modo de participação de agentes eruditos (professores, padres, cientistas sociais, profissionais de saúde e outros) neste trabalho político" (Brandão, 1982:42).

As práticas de educação popular nos anos 70 e 80 ficaram muito marcadas pelo contexto de sectarismo trazido pela ditadura militar, centrando-se na dimensão de luta política. Superado esse ambiente de sectarismo, é possível pensar uma ampliação da afirmação citada de Brandão e, utilizando o vocabulário do setor saúde, afirmar que educação popular é a participação de agentes eruditos no esforço de luta pela saúde (entendida de forma ampla) que os vários cidadãos já vem fazendo. O trabalho político é uma das dimensões desta luta. O educador é o profissional que usa a palavra e o gesto como instrumentos de trabalho nesta luta coletiva.

\section{Buscando novas estratégias de enfrentamento das doenças infecciosas por meio de uma pequisa-ação}

As reflexões que seguem se baseiam em pesquisa realizada em Belo Horizonte, no período de 1994 à 1997, como parte do Curso de Doutorado em Medicina Tropical da Universidade Federal de Minas Gerais. Com o objetivo de contribuir na explicitação, de forma mais clara, da metodologia de educação popular em saúde adequada ao atual contexto institucional e analisar o seu significado no combate às doenças infecciosas e parasitárias, buscou-se nesta pesquisa a inserção em um centro de saúde da periferia de Belo Horizonte (Centro de Saúde Vila Leonina, situado na região de favelas denominada Aglomerado Morro das Pedras), onde, ao se tentar dinamizar as suas práticas educativas, procurou-se identificar e entender os bloqueios e potencialidades existentes no relacionamento entre os profissionais e a população. Procurou-se mostrar a forma como as questões culturais, cognitivas e subjetivas dificultam e potencializam o funcionamento do serviço de saúde, indicando a necessidade de serem enfrentadas de forma explícita e sistemática pelas instituições de saúde. Trata-se, 
portanto, de uma pesquisa-ação com ênfase na observação participante, em que o envolvimento com os problemas de saúde de crianças desnutridas foi desencadeando uma série de mudanças no relacionamento do serviço com a comunidade local, mostrando que a educação popular não é uma atividade a mais que se desenvolve nos serviços de saúde, mas uma atividade que reorienta a globalidade de suas práticas. Nesse processo, verificou-se que as intensas e freqüentes manifestações de doenças infecciosas são, muitas vezes, conseqüências de problemas mais profundos na vida familiar, tendendo a se concentrar em famílias vivendo situações especiais de crise que são marginalizadas da rotina de atendimento de saúde orientado pela demanda espontânea.

Este estudo, centrando-se na busca de esclarecimento da dinâmica cultural e subjetiva presente no relacionamento entre o serviço de saúde e a população, não se preocupou em medir o impacto das estratégias delimitadas durante o processo de pesquisa. Como outras pesquisas qualitativas, partiu do pressuposto de que as relações sociais obedecem a regras estruturais recorrentes e que a observação de um pequeno universo (amostras estatisticamente irrelevantes, mas cuidadosa e intensivamente observadas) concede ao pesquisador a possibilidade de reconstituir, em ponto menor, processos que se verificam no nível mais amplo em um universo determinado. É uma metodologia de pesquisa particularmente útil quando se quer estudar situações e contextos globais e complexos.

Qual a possibilidade de generalização desse estudo de um problema teórico amplo realizado em um local circunscrito, baseado no acompanhamento de um número limitado de atores envolvidos? Os elementos estruturais e recorrentes da realidade estudada estão presentes, de alguma forma, em outras comunidades de periferia urbana, mas a generalização não pode ser imediata. As afirmações que se seguem referem-se à realidade estudada. A generalização e a aplicação em outras realidades se farão pela mediação do leitor, pela sua interpretação aplicada aos contextos em que estiver inserido. Será o leitor quem julgará se o texto oferece chaves de compreensão aplicáveis a sua problemática.

\section{Conhecer as formas de manifestação dos condicionamentos sociais mais gerais na particularidade das famílias locais}

Aplicando-se essa metodologia nos grupos do programa de combate à desnutrição do C. S. Vila Leonina, a abordagem da desnutrição, multiplicação dos ratos, parasitoses e infecções intestinais e outros problemas de saúde resultou numa significativa reorientação do processo pedagógico e da relação entre os profissionais de saúde e a clientela do programa. A educação popular, na medida em que problematiza e cria espaços de diálogo entre os atores envolvidos, propicia a construção e difusão de um novo conhecimento que, ao mesmo tempo, inova em relação ao conhecimento crítico em saúde e aponta para caminhos institucionais e organizativos mais adequados à superação dos problemas de saúde.

Já está bastante difundido entre os profissionais de saúde um conhecimento crítico que questiona a eficácia de intervenções médicas restritas às dimensões biológicas dos problemas de saúde. Há um amplo reconhecimento da importância de mudanças subjetivas, sociais e ambientais para a superação desses problemas. Têm-se proliferado estudos e publicações que discutem estas mudanças sociais e ambientais necessárias, mas esse conhecimento não tem resultado em mudanças significativas na prática técnica cotidiana dos serviços de saúde. Nos manuais médicos, por exemplo, essa abordagem social e crítica tem assumido um caráter de preâmbulo que antecede a abordagem técnica que continua inalteradamente guiada para a intervenção no corpo biológico, principalmente mediante o uso de medicamentos e aparelhos. Talvez isto ocorra por ser uma abordagem social e crítica ainda bastante abstrata, sem mediações com a prática clínica concreta. A educação popular e a pesquisaação contribuem justamente na medida em que possibilitam a construção de um conhecimento de mediação entre as análises estruturais e globais das ciências sociais em saúde e o conhecimento técnico específico.

A respeito da diarréia infantil, muitos livros de pediatria trazem considerações sobre a sua correlação com a pobreza, a má distribuição de renda, a precariedade das condições de saneamento a que são submetidas as classes populares e a baixa qualidade das escolas freqüentadas pelos pais. Porém, mesmo nestes livros e manuais, as intervenções preconizadas continuam centradas, quase que exclusivamente, na administração de soluções de reidratação, na utilização ou não de antibióticos e no manejo 
da alimentação. O conhecimento crítico das determinações sociais e ambientais da diarréia não resulta em condutas operacionais, a não ser difusas recomendações de valorizar ações educativas a respeito da higiene e da conscientização das causas estruturais da diarréia.

Durante uma reunião da Comissão Local de Saúde do C. S. Vila Leonina, foi discutida a morte de uma criança por diarréia. Ela vinha tendo episódios repetidos de diarréia, que, apesar de tratados, tinham-na deixado debilitada. No último episódio, ela faleceu, embora tenha sido devidamente medicada. A presidente de uma das associações de moradores locais era vizinha da família dessa criança e a visitara. Tratava-se de uma família muito pobre, com o pai doente e a mãe trabalhando fora vários dias da semana. A alimentação básica da criança era o leite fornecido na mamadeira. O leite era preparado (com adição de farináceos e açúcar) no início do dia e deixado em uma panela. Após cada mamada, a sobra do leite da mamadeira (contaminado pela regurgitação e contatos com moscas e mãos) era misturado com o restante que estava na panela, que apenas era levemente esquentado na véspera de nova mamada (elevando a temperatura do leite para algo próximo à temperatura ideal de multiplicação bacteriana). Não havia geladeira em sua casa. Com esse tipo de alimentação, a criança recebia freqüentemente, por via oral, grandes quantidades de bactérias patogênicas. Ela possivelmente teria sido salva se estes aspectos tivessem sido descobertos a tempo por visitas domiciliares desencadeadas pela repetição anterior dos quadros de diarréia. A 'correta' conduta terapêutica (em acordo com os ensinamentos dos manuais mais atualizados) da pediatra que a atendeu não considerou aspectos como aqueles, que não se apresentam como motivo de interesse da pesquisa médica. A má distribuição de renda, a opressão e a pobreza são causas de diarréia, mas atuam através da imposição de condições materiais específicas, condutas e posturas que variam em cada família e em cada situação social. "Que posturas são estas? Que condições são estas?” Quais as formas de abordá-las que já se mostraram viáveis?

O conhecimento do mecanismo de reinfecção desta criança, das condições ambientais de seu domicílio e vizinhança, da forma como sua família cuidava de sua saúde e da dinâmica de divisão de trabalho e de relacionamento afetivo ali existente (algo bastante particular à sua situação específica) é o que está se chamando de conhecimento intermediário entre as análises mais gerais das ciências sociais e o conhecimento técnico sobre a diarréia. Diante da complexidade e heterogeneidade das classes populares, só se tem acesso a estes aspectos particulares da clientela pesquisando no local. O conhecimento das ciências sociais, epidemiologia, microbiologia, fisiologia e clínica médica são fundamentais, mas insuficientes, para precisarem as múltiplas formas particulares como as condições econômicas, políticas e culturais gerais interagem e combinam com as condições ambientais e os agentes etiológicos, para resultarem nos danos no corpo humano conhecidos pela patologia médica. É nesse nível mais particular da vida social que o serviço local de saúde tem maiores condições de intervir coletivamente.

$\mathrm{Na}$ abordagem clínica e educativa de pacientes com condições culturais e econômicas semelhantes às dos profissionais de saúde, essa insuficiência do conhecimento social e médico não é tão gritante, porque as particularidades da clientela são intuitivamente entendidas pelo profissional por causa da similaridade com sua própria vida. Ao mesmo tempo, as afirmações e recomendações dos profissionais de saúde são melhor entendidas e contextualizadas por esta clientela com condições sociais e culturais semelhantes.

$\mathrm{Na}$ rotina de trabalho apressada de um serviço de saúde destinado às classes populares, em que a infra-estrutura disponível quase sempre é menor do que a demanda, é difícil esperar o envolvimento de seus profissionais em pesquisas mais amplas. O método da educação popular é uma estratégia de intervenção (e portanto mais assimilável à cultura intervencionista do setor saúde) que prioriza a criação de espaços de diálogo em que problemas específicos são debatidos de uma forma que valoriza a explicitação e incorporação dos saberes e reflexões dos cidadãos envolvidos. Possibilita aos serviços de saúde a construção de conhecimentos e práticas mediadores entre a abordagem restrita ao biológico e aquela mais abstrata e genérica das ciências sociais. Possibilita ainda às famílias e aos grupos populares a aquisição de conhecimentos técnicos necessários à maior eficiência de suas lutas por melhores condições de saúde.

Não basta criticar os serviços de saúde por não abordarem dimensões coletivas dos problemas de saúde. É preciso construir conhecimentos operacionalizáveis que permitam fazêlo. Na urgência dos problemas que chegam, um atrás do outro, o profissional é pressionado a implementar técnicas que já se mostraram operacionalizáveis, ainda que esteja consciente de seu caráter restrito e limitado. O processo vivenciado nesta pesquisa mostrou a potencia- 
lidade da metodologia da pesquisa-ação no delineamento de formas de intervenção coletiva operacionalizáveis nos serviços de saúde. O acompanhamento diferenciado às famílias em situação de risco, o apoio ao saneamento da Vila Pantanal integrado às iniciativas de suas famílias e organizações e a construção coletiva das propostas para o enfrentamento do problema do lixo no Aglomerado Morro das Pedras são alguns dos exemplos.

Trata-se de uma metodologia de construção de novos caminhos de intervenção coletiva diferente do caminho habitualmente utilizado de acionamento de assessorias especializadas. Em vez de uma seqüência de consultorias, os vários atores técnicos e populares envolvidos buscaram se debruçar, em conjunto, sobre os problemas de saúde que enfrentavam, numa relação que procurava se orientar pelo diálogo (Valla, 1993:99) e na qual os espaços educativos significavam também momentos de compartilhamento das descobertas e de síntese. Assessorias de especialistas externos ao serviço, se não estão engajadas no movimento de pesquisa participativa dos problemas sanitários locais, resultam em conhecimentos e práticas desvinculados do contexto e das particularidades da região e dos atores profissionais e populares envolvidos.

Esse processo participativo, apesar de ser demorado e extremamente exigente de investimento profissional, mostrou ser vantajoso, uma vez que não apenas gera novos conhecimentos, mas os difunde e também desenvolve novas formas de organização institucional e de relacionamento com os grupos populares. Assim, o processo de visitas às famílias com desnutridos para melhor entendimento de sua dinâmica interna já foi gestando também o programa de acompanhamento às famílias de risco. Foi resultando também num aprendizado de vários profissionais e membros da Comissão Local de Saúde e dos grupos do programa de combate à desnutrição sobre as raízes e estratégias de enfrentamento das conseqüências e causas desse problema.

O processo de pesquisa-ação não apenas gerou novos conhecimentos, como também constituiu novos instrumentos de intervenção terapêutica em que a abordagem coletiva era priorizada. Tais instrumentos de intervenção foram gestados já em acordo com os interesses e peculiaridades dos atores locais. Resultou ainda na constituição de novos agentes terapêuticos (profissionais ou não) e na reciclagem e fortalecimento de outros.

Nessa perspectiva de pesquisa e ação orientada pelo método da educação popular, os en- traves institucionais, as oposições políticas, as deficiências de formação técnica, as intrigas, os fracassos, as resistências e os conflitos são encarados como manifestações de outras lógicas e interesses ou de dimensões da realidade que não estavam sendo levadas em conta anteriormente. Ao invés do enfrentamento direto e pessoal de tais dificuldades, o educador deve procurar trazê-las para o espaço de debates, buscando estudar, traduzir e explicitar os interesses, razões e significados simbólicos que se escondem por trás de suas manifestações. Já que também se investe para que os atores mais subalternos estejam fortemente presentes nestes espaços educativos e de negociação, o enfrentamento das dificuldades será algo compartilhado. Os novos conhecimentos e práticas, sendo uma construção coletiva, são enriquecidos pela diversidade dos participantes e refletem a negociação e o poder dos vários atores envolvidos.

A busca da saúde, nessa perspectiva, transforma-se num jogo em que o tabuleiro não é mais o serviço de saúde, mas a sociedade civil. Nesse jogo, os constrangimentos institucionais, a subordinação política, a carência de recursos e as limitações do conhecimento científico continuam a participar como personagens importantes que, no entanto, não conseguem segurar e imobilizar com suas mãos a fluidez das palavras, idéias e solidariedades a se intercombinarem, gerando práticas e saberes imprevisíveis. Assim, o trabalho em saúde adquire sentidos e simbolismos que tornam seu cotidiano colorido e carregado de surpresas e mistérios, ajudando a enfrentar a desgastante convivência com a dor, a morte e o descaso político.

\section{Doenças infecciosas e miséria. O cuidado de famílias em situação de risco como estratégia de enfrentamento da exclusão social}

Nas últimas décadas, assistiu-se a uma significativa diminuição da importância das doenças infecciosas como causa de morte e sofrimento para um amplo setor das classes populares. No Aglomerado Morro das Pedras percebeu-se, no entanto, a existência de uma ampla heterogeneidade na situação de diferentes famílias em relação ao impacto causado por esses agravos. Para muitas famílias, as doenças infecciosas e parasitárias corriqueiras, mesmo sendo freqüentes devido às condições ambientais e humanas favorecedoras do contágio, são logo tratadas e normalmente não chegam a causar repercussões mais profundas na saúde de seus 
membros, manifestando-se através de quadros leves e transitórios. Para outras, contudo, essas doenças estão sempre presentes, em grande número, entre seus membros, resultando em intensa espoliação do organismo e na presença de manifestações clínicas exuberantes. Só são tratadas quando assumem dimensões mais graves. Tal situação acontece principalmente em famílias vivendo contextos de crise, seja por desemprego, ou doenças dos pais, dependência de drogas, atritos conjugais, presença de grande número de filhos pequenos, migração recente, envolvimento com atividades ilícitas e perseguidas pela polícia etc. Tais famílias têm sido denominadas de "famílias em risco" (Takashima, 1994). Entre esses dois tipos polares, existem famílias em situação intermediária.

Estudos epidemiológicos (Mendonça, 1995) têm mostrado como a maioria das mortes em crianças por doenças infecciosas acontecem em famílias vivendo em situações especiais de risco. Assim, a atenção diferenciada a essas famílias pode ter um significativo impacto na redução da mortalidade infantil. Ao mesmo tempo, repetidos relatos colhidos nesta pesquisa indicam que essas famílias vivendo situações de crise e com membros intensamente acometidos por doenças infecciosas e parasitárias corriqueiras representam fontes importantes de irradiação e contágio para o restante das famílias. É possível então sugerir que o acompanhamento diferenciado a tais famílias possa ter um importante impacto na freqüência e na intensidade de acometimento de muitas doenças infecciosas e parasitárias na população como um todo.

No processo de acompanhamento a famílias em situação de crise iniciado no Aglomerado Morro das Pedras durante este estudo, verificou-se que as freqüentes e intensas manifestações de doenças infecciosas e parasitárias em suas crianças eram conseqüências de problemas mais profundos na vida familiar. Assim, o diagnóstico de manifestações intensas de patologias facilmente tratáveis com os recursos médicos atuais passou a ser utilizado como indicador de situação familiar necessitando de maior acompanhamento. Percebeu-se que a simples prescrição de medicamentos para essas patologias, sem um continuado cuidado e acompanhamento familiar, tinha poucas repercussões na situação de saúde das crianças. Constatou-se ainda que o atendimento dos serviços de saúde a partir da demanda espontânea termina por marginalizar este tipo de família, uma vez que seus responsáveis têm dificuldade de competir nas filas e no cumprimen- to dos prazos e prescrições para conseguirem o acesso ao atendimento necessário.

A complexidade evidenciada por trás de infecções aparentemente tão simples nos membros destas famílias questiona profundamente a racionalidade médica hegemônica. Esta funciona segundo um modelo racionalista que busca definir e explicar o problema (a doença) para perseguir uma solução racional tendencialmente ótima (a cura). A terapia não é tanto uma relação de cuidado e atenção do médico ao paciente, mas um processo de abordagem organizado (com teorias, normas e intervenções padronizadas) que busca definir com precisão um diagnóstico para chegar ao prognóstico e à cura. Mas a situação de miséria social, em que as múltiplas doenças infecciosas e parasitárias são apenas um dos sintomas, delimitam problemas familiares concretos (marcados pelo alcoolismo, violência conjugal, negligência, imundície, doença mental, desespero, delinqüência, conformismo ou deficiência física) que de tão complexos não se consegue entender com profundidade e precisão, sendo, portanto, bastante 'não conhecíveis' e incuráveis. Apesar dos enormes esforços para dar-lhes uma definição racional, ampliando e tornando mais complexo o quadro de causas mediante as contribuições das pesquisas em psiquiatria social, epidemiologia, antropologia, sociologia, nutrição e ciências políticas, esses problemas continuam se mostrando amplamente indefinidos. Apesar dos avanços das psicoterapias, da farmacologia, das técnicas de saneamento ambiental, das dinâmicas educativas, das técnicas de medicina preventiva e mobilização comunitária, a cronicidade destas situaçõesproblema perdura ostensivamente no contexto de uma sociedade industrializada, moderna e injusta. Uma cronicidade que é o sinal mais evidente da impotência da medicina em alcançar a solução-cura das doenças infecciosas e parasitárias em famílias subjugadas pela miséria.

Diante da legitimidade do sistema de saúde, conseguida em grande parte por sua aparência racional, esses sujeitos repetidamente infectados e espoliados se envergonham e se afastam depois de cansarem de procurar e serem encaminhados para diferentes profissionais, sem obterem a almejada cura. Nesse sistema funcionando com base na racionalidade problema-solução, a solução disponível acaba amoldando a forma como o problema é definido e classificado. Os serviços passam a selecionar os problemas com base na sua própria competência. Ao restante, é como se dissessem: “- O problema não é nosso". 
Nesse contexto, os programas de combate à desnutrição acabam assumindo o papel de descarga das crianças cujos repetidos problemas de saúde não são resolvidos integralmente pelo sistema de saúde e, assim, vão tendo seu corpo degradado progressivamente. Juntamente com os serviços de psiquiatria, as classes especiais de crianças-problema de algumas escolas, os reformatórios e as delegacias de polícia, que também recebem os mais fragilizados pela miséria social, vão administrando o que sobra deste sistema de assistência social que classifica como incoerente e insolúvel o que não se enquadra nas soluções que é capaz de oferecer.

Reconhecer a impossibilidade de conhecer e classificar com precisão essas situações familiares extremas e construir uma solução para a sua cura não significa, em absoluto, renunciar a tratar e a cuidar delas. Possibilita, pelo contrário, uma mudança de ótica profunda e duradoura que atinge o conjunto das políticas sociais que atuam junto aos miseráveis. Tais constatações ganharam repercussão internacional no setor saúde a partir da experiência italiana de reforma psiquiátrica (Rotelli et al., 1990:22-33).

Os problemas das famílias em situação de risco do Aglomerado Morro das Pedras eram muito profundos e complexos para serem curados, mas não para serem cuidados. Cuidando de forma sistemática e persistente de problemas específicos, dimensões mais gerais destes iam se manifestando e quase sempre tínhamos alguma contribuição a oferecer. Nesse cuidado, ocorria progressivamente uma aproximação entre a equipe de saúde e a família, que ampliava as possibilidades de uma ação educativa voltada para a valorização do potencial de criatividade e liberdade de seus membros.

Se não se pode conhecer e classificar com precisão a multiplicidade de situações-problema impostas às famílias mais vulneráveis pela miséria social, isto não quer dizer que não se possam buscar entendimentos parciais que orientem os cuidados a serem prestados. Neste sentido, uma postura problematizadora na ação educativa e o desenvolvimento de pesquisas participativas podem esclarecer aspectos importantes.

O intenso acometimento por doenças infecciosas e parasitárias corriqueiras em alguns indivíduos pode, portanto, ser a manifestação de situações familiares de risco que necessitam de uma atenção orientada por uma racionalidade diferente daquela que domina o atendimento médico nos serviços de saúde. Esses pacientes necessitam não tanto de um atendi- mento voltado para classificar, diagnosticar e tratar suas patologias específicas, mas de uma atenção diferenciada e continuada para sua família como um todo. São famílias que, subjugadas pela miséria, tornaram-se extremamente vulneráveis pela combinação de diferentes particularidades de caráter social e pessoal, mostrando-se incapazes de tomar a iniciativa de implementar e articular o cuidado pleno de seus membros. O direito de cidadania desses membros incapazes de iniciativas próprias (principalmente as crianças, os idosos e os portadores de doenças incapacitantes) não pode ficar dependente de pais e parentes que estão vivendo situações de crise. É necessário que os serviços sociais, inclusive os de saúde, intervenham nestas famílias, responsabilizando-se pela dinamização da atenção a seus membros enquanto durar a situação de crise familiar. A identificação e o cuidado sistemático destas famílias em situação de risco podem levar a um importante impacto no controle da mortalidade e morbidade por doenças infecciosas e parasitárias (e outras patologias) em uma comunidade, elevando a eficácia dos serviços de saúde de forma pouco onerosa.

É, portanto, fundamental a ampliação e aperfeiçoamento do Programa de Saúde da Família em implantação no Brasil desde 1994. A atenção diferenciada a famílias vivendo situações de risco não é uma estratégia sanitária apropriada apenas para regiões carentes que ainda não conseguiram desenvolver serviços médicos sofisticados, como querem acreditar muitos sanitaristas (Misoczky, 1994), mas uma estratégia de aprofundamento da qualidade dos serviços diante da complexidade das situações de exclusão social tão fortemente presentes até mesmo nas regiões mais industrializadas e modernas da sociedade capitalista contemporânea. A necessidade de a sociedade e de o Estado se responsabilizarem por essas famílias correlaciona-se com o reconhecimento social do caráter excludente e perverso do atual modelo de desenvolvimento econômico.

Neste sentido, os resultados desta pesquisa reforçam a ênfase que organismos internacionais como o Unicef e a OMS vêm dispensando à priorização da abordagem familiar (principalmente àquelas em situação mais vulnerável) na reorientação das políticas sociais (Maurás \& Kayayan, 1994:9) 


\section{Perplexidades e reações dos profissionais diante da miséria}

Visitando as 49 crianças em situação de desnutrição grave mapeadas pelo Centro de Saúde, fomos percebendo que a desnutrição é também um marcador de famílias vivendo situações especiais de muita carência. Se, em algumas delas, a desnutrição se devia a fatores transitórios em processo de superação, na maioria das vezes era a manifestação de crises familiares profundas que inviabilizavam o cuidado global das crianças. Assim, o combate à desnutrição dependia de ações muito mais amplas do que os conselhos de normas higiênicas e alimentares e a entrega mensal de alguns pacotes de alimento. Na equipe, começa então a surgir uma grande dúvida e angústia: diante de problemas tão complexos e variados, nós, profissionais de saúde, temos alguma coisa a fazer?

Além da sensação de incapacidade diante da complexidade dos problemas percebidos, os profissionais, muitas vezes, eram tomados por momentos de depressão. A miséria se mostra de formas muito variadas. Quando se começava a acostumar com alguma situação, uma nova face da miséria se mostrava. O motorista do carro certa vez comentou: “- Quando vocês saem para as visitas vão alegres e falantes. Quando voltam, estão calados e olhando para o chão". A favela está sempre surpreendendo. De repente estávamos em becos de aspecto tão estranho, que nem pareciam fazer parte da favela que já conhecíamos. Cada família causava-nos impacto por motivos diferentes. Ora era o conflito entre seus membros, ora o alcoolismo ou a falta radical de recursos, a sujeira, o excesso de crianças espremidas em um cômodo, os olhares agressivos, a criança desamparada, o caos doméstico pela doença da mãe, a violência, a falta de perspectiva, a dor ...

A dor que pulsa na miséria se expressa, às vezes, por detalhes ou circunstâncias até pitorescos. Estávamos procurando o endereço de uma família e descobrimos um grupo de crianças que a conhecia. Elas se prontificaram a nos levar lá. Ficaram excitadas em entrar no carro. No caminho, uma das crianças, pensativa, nos disse: “- Nós nunca tínhamos andado de carro antes... Só no carro da polícia”.

As visitas, no entanto, não despertavam apenas tristeza e compaixão na equipe; despertavam também raiva e indignação com aspectos que pareciam incoerências, desperdício e alienação naquelas famílias. Os sentimentos da equipe oscilavam também na dependência dos entraves institucionais a que os técnicos eram submetidos. Certa vez, um profissional explicou por que não queria ir às visitas programadas: "- Esse pessoal (os moradores) não merece o meu esforço. São tantas as decepções..."

Muitas constatações chocavam a equipe: a presença freqüente de televisões e aparelhos rústicos de som em casas onde se dormia em camas com colchões imundos e rasgados e onde não se tinha nem mesmo banheiros; a presença de jovens aparentemente ociosos e com atitudes de pouca preocupação e empenho com o progresso profissional e cultural; a ausência de revolta evidente apesar da situação de precariedade existente, ao lado da falta de interesse em participar de atividades associativas e mobilizações políticas; um certo conformismo e, às vezes, até alegria apesar da miséria; a resistência em colocar em prática as orientações dos profissionais, aparentemente tão lógicas; os freqüentes e intensos conflitos dentro das famílias ou entre vizinhos e os repetidos atos de violência narrados, quando seria tão necessária a união e o apoio mútuo; a incoerência e a contradição percebidas em muitas de suas falas.

Um exemplo marcante da reação de raiva e indignação com as famílias aconteceu com a assistente social que começara a fazer uma pesquisa, por meio de entrevistas, com mães das crianças mais gravemente desnutridas do programa. Entrevistando Carmem Lúcia, de 21 anos e cinco filhos, a maioria desnutridos, ficou revoltada com sua apatia e irresponsabilidade. Apesar de viver uma situação de vida precaríssima, não se dispunha a tomar nenhuma das três iniciativas de enfrentamento propostas pela assistente social: esterilizar-se, buscar conseguir pensão junto à previdência social para dois irmãos deficientes físicos com quem morava (não acreditava ser viável) e entrar com ação judicial contra os diferentes pais de seus filhos. A partir da revolta da assistente social, discutiu-se muito se o programa de apoio aos desnutridos não acabaria reforçando a acomodação das mães e incentivando-as a ter mais filhos. Para essa assistente social, a raiz da desnutrição da maioria das crianças estava em problemas de ordem psicológica que não eram abordados pelo programa. Essas discussões polarizavam a equipe e dividiam as opiniões de outros profissionais que se aproximavam.

Dez dias depois da entrevista de Carmem Lúcia, fomos visitá-la em casa. Era uma casa de tijolo, não rebocada, com três cômodos separados por divisórias de papelão. Mora com irmãos (por parte do pai) e a mãe, que, falante, logo se fez o centro da conversa, contando sua história. Ela morava no interior e era a filha 
mais velha. Tendo sua mãe morrido, assumiu o cuidado dos irmãos. Seu pai a casou com 13 anos com um amigo e vizinho, bem mais velho, para que não fugisse de casa e, assim, continuasse a cuidar dos irmãos. Não tinha noção de vida sexual, chegando a se revoltar com o marido quando este, um dia, pediu-lhe um beijo. Mas após os 16 anos passou a ter filhos quase anualmente. Quando já tinha dez filhos, seu marido a largou para ir morar com sua madrasta (seu pai, antes de morrer, casara-se novamente), levando todos os filhos. Estava gestante na época e, desesperada, ficou a vagar pela cidade com fome, envergonhada de pedir esmola. Mas uma senhora, percebendo a situação, aproximou-se e a chamou para sua casa. Quando a filha nasceu, alugou um barraco e passou a trabalhar fazendo serviços domésticos. Deixava a filha, Carmem Lúcia, recémnascida, trancada no barraco para ir trabalhar. Quando voltava, ela estava sempre suja de fezes e desesperada. Procurando melhor salário, veio para Belo Horizonte com Carmem Lúcia. Passou por várias favelas, sempre lavando roupa, deixando a filha sozinha em casa para ir trabalhar. Assim, Carmem Lúcia foi criada 'largada'. Quando ela se tornou adolescente, começou a ter companheiros, tendo morado com vários homens, a maioria alcoólatra e sem emprego fixo. De companheiro em companheiro, foram nascendo seus cinco filhos. Na época da visita, estava grávida novamente. Com a morte, no interior de Minas, do pai de Carmem Lúcia, cinco dos seus irmãos (por parte do pai com a outra esposa) vieram morar com a mãe de Carmem, sendo um paralítico e outro com doença mental. Os filhos de Carmem estão com muita verminose e com anemia, mas ela só os leva ao Centro de Saúde em casos de crise. Para ela, é difícil chegar cedo para conseguir as fichas para consulta médica e os médicos sempre pedem exames laboratoriais que exigem repetidas idas a laboratórios distantes.

Diante da evidente complexidade da história de Carmem Lúcia, a equipe se calou. Em muitas situações, não se encontram palavras capazes de expressar a profusão de sentimentos, percepções e pensamentos desencadeados. Mas, no silêncio, compartilhamos nossa estupefação. Qualquer julgamento seria precipitação.

Há um movimento da ciência de buscar enquadrar situações particulares em padrões explicativos mais gerais desenvolvidos em estudos anteriores. Dessa forma, busca-se trazer para o enfrentamento de uma situação particular a experiência já adquirida. Assim, analisar e classificar a postura de uma família ou um paciente tem sentido como estratégia de orientação dos caminhos do cuidado e do tratamento a ser dispensado. Mas aquilo a que se assistia, muitas vezes, era a tendência de analisar e classificar as posturas da clientela como uma forma de avaliar o merecimento ou não dos cuidados disponíveis no serviço. Era uma análise que, apesar de se revestir de conceitos sociológicos e psicológicos, centrava-se num julgamento moral do morador, buscando enquadrá-lo como acomodado ou esforçado, estúpido ou ativo, desonesto ou bem-intencionado. Esse julgamento moral é inerente às relações humanas, mas, na relação entre os profissionais de saúde e a clientela popular, tendia a ser apressado, sem um movimento prévio de busca de entendimento dos comportamentos não compreendidos inicialmente. Pelo contrário, o julgamento moral imediato bloqueava a iniciativa de esclarecimento, e a sua enunciação como se fosse uma análise científica conferia-lhe uma rigidez que dificultava o seu questionamento.

Os profissionais de saúde, impressionados com a miséria, tendem a esperar que os moradores das periferias urbanas estejam sempre mobilizados, numa constante busca racional de melhores condições de sobrevivência. Mas, como diz a música do conjunto Titãs: “- A gente não quer só comida. A gente quer prazer para aliviar a dor". Assim, a televisão, o jogo, a descontração, o ócio, não significam apenas formas de escapar da realidade, mas podem estar indicando uma concepção de vida mais ampla do que aquela que o técnico quer impor-lhes. Indicam que a vida vale a pena, mesmo sem perspectiva de uma saída para o sofrimento e a pobreza que se tem que aturar diariamente.

Outras vezes, o que para o profissional é comodismo, falta de iniciativa e apatia, para a população é uma avaliação rigorosa dos limites da sua melhoria. A clareza de uma análise social pode ser a percepção de que a melhoria ou solução proposta pelo técnico é, antes de tudo, um desejo de alguém angustiado com a situação de pobreza ou de seu interesse em mostrar competência na instituição de origem. A população convive muito proximamente com a força dos mecanismos de coerção e exclusão sociais. A lucidez pode ser o descrédito de determinada proposta de mudança, a não ser que se crie ou se configure uma situação de mudança no jogo de forças políticas (Valla, 1996).

Há uma tendência de se perceber a luta popular por mudanças sociais apenas quando ela se manifesta por formas tradicionais de mobilização política: reuniões, formação de entidades organizadas, manifestações públicas, en- 
frentamento coletivo, participação em partidos políticos. Mas a resistência e luta política vão além destas formas. A resistência pode ser difusa: a irreverência do humor e da ironia, o silêncio, a não-participação nas reuniões, o olhar de desaprovação, a criação de práticas alternativas ou o discurso de aparente aceitação, mas entremeado de sutis ressalvas que o desdizem.

A valorização dessas formas difusas de resistência ganhou importância a partir dos estudos de Foucault (1985), que criticou as análises da esquerda sobre o poder, na medida em que se centram basicamente nos grandes aparelhos estatais e na burguesia. O poder seria algo mais difuso. O poder funciona e se exerce em rede. Nunca está localizado aqui ou ali, nem está só na mãos de alguns. Não é a dominação global que se divide e repercute, de cima para baixo, no tecido social. A dominação geral pode funcionar porque se sustenta em micropoderes, com relativa autonomia, que acontecem oriundos de múltiplos atores sociais. Os indivíduos não são alvo inerte ou consentido do poder, são sempre pontos de transmissão, reorientação ou reforço dele. Para se entender o poder, é preciso buscar perceber as táticas e técnicas de dominação no detalhe da vida social e procurar compreender como os diversificados mecanismos de poder são utilizados, transformados e ampliados pelas formas mais gerais de dominação. É necessário também esclarecer como os interesses mais gerais se inscrevem, acontecem e são reorientados no nível do cotidiano. O poder, para se exercer, precisa produzir, organizar e colocar em circulação saberes que o tornem legítimo. A partir dessa contribuição de Foucault, as práticas cotidianas de conformismo e resistência que acontecem no cotidiano da vida passam a ser centrais, respectivamente, na sustentação e na superação da dominação que marca a sociedade. Assim, a luta pela transformação das dimensões políticas do processo de adoecimento na sociedade se descentraliza das instâncias partidárias, do aparelho estatal de direção política e do comando das grandes empresas para se estender também às cumplicidades, apoios e resistências que envolvem todo o tecido social. Os trabalhadores e cientistas sociais que até a década de 80 estiveram preocupados essencialmente, em suas discussões, com as questões da Revolução e Contra-Revolução, passam a se debruçar sobre os temas dos micropoderes (Neder, 1994:35).

Somente prestando atenção nas dimensões subjetivas e culturais, podem-se compreender muitas das razões da resignação dos pobres diante de situações revoltantes para os técni- cos. Não é a simples falta de determinado recurso material que leva à revolta ou ao empenho na mudança. O que é considerado necessidade para uma vida digna, em cada região, depende do padrão de vida tradicional (as condições em que as pessoas daquele grupo social vêm sendo historicamente criadas). O conjunto de carências aceitas como legítimas e, portanto, considerado como uma obrigação do Estado e do sistema produtivo varia, continuamente, em virtude das lutas sociais, da capacidade de persuasão dos atores em disputa e dos recursos das instituições políticas e econômicas existentes. É necessário que haja uma atividade de elaboração mental dos indivíduos no sentido de refletir a vivência da miséria e da pobreza material, sem o que não existirá nenhuma percepção de carência.

Desse ponto de vista, a elevação da taxa de mortalidade infantil ocasionada pela contaminação do lençol freático das periferias e pela presença de esgotos a céu aberto não determinaria, por si, a elaboração da percepção de carência de equipamentos de saúde e saneamento, ainda que esta taxa pudesse chocar enormemente os profissionais de saúde locais. Somente é possível sentir carência de algo que já pertença a cultura local. E entre as várias possibilidades de privilegiamento e hierarquização das várias carências existentes entram em jogo necessariamente uma escolha individual ou do grupo social com base em de seus valores e circunstâncias locais envolvidas. É por isso que a população costuma rejeitar os chamados alimentos alternativos defendidos por técnicos empenhados no combate da fome, que propõem a substituição de seus alimentos tradicionais por alimentos mais baratos e com maior quantidade de nutrientes. Os trabalhadores não sentem carências de $x$ calorias, $y$ gramas de proteínas ou $z$ unidades de vitamina por dia. As pessoas têm carência de determinados alimentos, que devem ser consumidos de determinada forma, de acordo com a tradição peculiar de cada sociedade ou de cada grupo social nas sociedades complexas. As carências que motivam o esforço dos indivíduos e grupos passam necessariamente pela subjetividade e pela cultura (Nunes, 1989). São, portanto, também construídas e redefinidas nas práticas educativas, mas, naquelas que não partam do pressuposto da existência de uma associação linear entre a vontade da população e as carências materiais definidas pela ciência. 


\section{Mingau quente se toma pelas beiradas}

No processo de aproximação e acompanhamento das crianças desnutridas pelo C. S. Vila Leonina, fomos descobrindo o que depois constatamos ser o princípio norteador do Ano Internacional da Família - 1994, promovido pela ONU: "A família como instrumento essencial de preservação, transmissão de valores culturais, instituição que educa, forma e motiva o homem e merece uma atenção especial de proteção e assistência" (Takashima, 1994:77-78).

A família é o meio no qual acontecem e se administram os cuidados básicos com o corpo, ocupando, portanto, um papel central na formação e preservação biológica dos indivíduos. É também onde se transmitem os ensinamentos mais fundamentais para o convívio social. Mais ainda: sendo local privilegiado de vivência do afeto, da intimidade e propiciando o sentimento de pertencimento, tem um papel fundamental na formação da identidade do indivíduo e na construção, na sociedade, da noção de cidadania. Mesmos entre os mais miseráveis do Aglomerado Morro das Pedras, a família se mostrou como eixo central de sobrevivência e preservação do mínimo de dignidade e felicidade.

Apesar da expectativa aparentemente dominante na sociedade de que o trabalho dos serviços de saúde se concentre na preservação biológica dos indivíduos, percebemos que não tinha sentido restringir o acompanhamento e o apoio às famílias atendo-nos apenas aos cuidados de higiene, mudança de comportamentos prejudiciais à saúde, tratamento e prevenção de doenças, saneamento etc. Esses aspectos, diretamente vinculados à prática tradicional de saúde, mostraram-se, na maioria das vezes, como campos de manifestação de problemas decorrentes de dimensões psicossociais mais gerais. Além disso, atuar apenas para alongar a sobrevivência biológica é um objetivo muito limitado. Sobreviver é pouco. Uma atuação voltada de forma restrita ao biológico tem sentido dentro de uma racionalidade econômica capitalista que se interessa essencialmente pela reprodução da força de trabalho como forma de assegurar o controle das faltas no emprego, a capacidade produtiva do operário e a manutenção de uma ampla reserva de trabalhadores disponíveis para não permitir a elevação dos salários. Isso interessa também às forças políticas dominantes, ansiosas por divulgar a melhoria dos indicadores de saúde conseguida com os limitados recursos que colocam à disposição das políticas sociais. Assim, o trabalho de acompanhamento às famílias em situação de risco pelo C. S. Vila Leonina se colocava, se bem que nem sempre muito claramente, numa perspectiva de não se restringir ao controle de problemas de saúde específicos, mas buscando apoiar a luta daqueles moradores pela vida, entendida de forma mais ampla. Nesse sentido, o cuidado com as crianças desnutridas passou a ser uma estratégia de aproximação da família e de resgate do gosto e o carinho pela vida, importantes tanto para a criança, como para os pais. A melhora da saúde de uma criança promove a elevação da auto-estima de toda a família, recompondo parte do sonho de um futuro melhor, onde os filhos são centrais. A saúde, alegria e criatividade dos filhos altera a identidade dos pais.

Apoiar a luta da família pela vida: este objetivo aparentemente simples era sempre ameaçado pelo estranhamento e até rejeição por parte dos profissionais aos caminhos escolhidos pelos moradores do Aglomerado. Marcados pelo preconceito, muitas vezes eles não tinham paciência para buscar entender a lógica destes caminhos diferentes. Não se pode contribuir para que os membros de uma família assumam sua caminhada no sentido de serem sujeitos ativos de suas vidas e da história da sociedade, se os tratamos de forma desprezível e autoritária como se detivéssemos o conhecimento do melhor caminho para eles. Os profissionais, preocupados em apoiar a luta das famílias pela vida, debatiam-se sempre entre estes dois pólos: o desprezo e o respeito às manifestações concretas de suas escolhas.

Ao lado da desnutrição, verminose, anemia ferropriva e infecções dermatológicas, respiratórias ou urinárias, encontrávamos alcoolismo, conflito conjugal, desemprego, doença mental, perseguição da polícia, briga entre quadrilhas, desânimo com a vida, salário insuficiente, condição de moradia desumana, falta de saneamento, rejeição social e tantos outros problemas psicossociais que estavam muito além da capacidade da equipe de saúde. Mas percebemos que, na medida em que íamos abordando problemas específicos de saúde, dimensões mais gerais destes problemas iam se manifestando e quase sempre tínhamos alguma contribuição a oferecer. No Centro de Saúde, essa metodologia foi denominada pela expressão popular "mingau quente se toma pelas beiradas". Atuando de forma sistemática e persistente sobre as manifestações periféricas dos problemas mais gerais, era possível perceber significativa influência sobre dimensões mais centrais dos problemas familiares.

Os problemas daquelas famílias, possivelmente as mais miseráveis entre as existentes 
naquela favela, eram muito profundos para serem 'curados', mas não para serem cuidados. Cuidar significa ocupar-se, aqui e agora, dos problemas passíveis de serem enfrentados, colocando-se à disposição de acordo com as condições exigidas pelos mesmos e não com aquelas condições oferecidas tradicionalmente pelo serviço. O sofrimento não se anula, mas começa-se a remover-lhe motivos e mudam-se as formas e o peso com que esse sofrimento entra no jogo da vida da família. Cuida-se dessas famílias em situação de risco não como prêmio por perceber seu esforço ou sua assimilação das orientações da equipe, mas como resposta ao direito à cidadania de sujeitos vivendo situações que não lhes permitem buscar e lutar pelos recursos existentes nos precários e limitados serviços de saúde destinados às classes populares. O apoio familiar não pode ser um último teste para aquela família se tornar operativa, mas um espaço de vida a mais no qual lhe propiciamos alguns novos suportes que possa utilizar para recompor seu próprio caminho de vida. Fazer-se responsável por membros incapazes de iniciativas próprias e em crise de uma família é evitar seu abandono em nome de uma propalada liberdade que as pessoas teriam para, inclusive, não querer cuidar de sua saúde ou da de seus dependentes, sem deixar, no entanto, de respeitar suas diretrizes de vida.

O trabalho com famílias em situação de risco tem um percurso dinâmico em contínua transformação, feito de tentativas, erros e aprendizagens, no qual os objetivos mudam durante o percurso porque são modificados pelos sujeitos acompanhados (Rotelli et al., 1990:33-35).

O eixo desse trabalho é a educação (Takashima, 1994), mas uma educação na perspectiva sintetizada por Paulo Freire, que se centra no reconhecimento e valorização do potencial humano para a criatividade e a liberdade, mesmo no interior de estruturas político-econômico-culturais opressoras. No processo educativo em que as pessoas atingem a compreensão, tanto da realidade cultural em que estão, inseridos como da capacidade que têm para transformá-la, vão se descobrindo e se implementando formas alternativas e libertadoras de relação social, bem como novas formas de organização da vida social, institucional e política (Gerhardt, 1996:168).

Responsabilizar-se por essas famílias em situação de risco não significa necessariamente a ampliação da intervenção estatal na vida social de uma forma a aumentar o seu controle, agora, até mesmo sobre as famílias que na pers- pectiva capitalista parecem ser as mais resistentes à lógica de progresso e modernidade. A experiência no Aglomerado Morro das Pedras aponta para uma nova possibilidade de intervenção dos serviços de saúde, que, ao contrário de ampliar a passividade da sociedade diante de um Estado autoritário que tenta prover as necessidades sociais por meio de intervenções burocratizadas e normatizadoras guiadas pela lógica cultural dos grupos dominantes, busca apoiar as redes de solidariedade social existentes em torno dessas famílias, procurando melhor articulá-las mediante enfrentamento de mal-entendidos bloqueadores de sua plena operacionalização.

Cuidar de famílias em situação de risco mostrou ser também um ato transformador da própria instituição de saúde. Estender o atendimento do Centro de Saúde para além dos limites de seu prédio resultou no acesso a informações sobre a dinâmica de vida e de adoecimento daquela população que foram difundidas para outros profissionais. Resultou ainda em questionamentos a condutas antes rotineiras, além de possibilitar o contato e o envolvimento de outros atores sociais presentes na região, mas até então desconhecidos pelo Centro de Saúde. Alimentou o ânimo e a criatividade de vários profissionais, ajudando a transformar dificuldades em desafios.

Sair para a comunidade cria problemas internos no Centro de Saúde. Mas, na gestão desses problemas se modifica a cultura dos atores em jogo. As oposições, as reclamações pelas outras prioridades abandonadas, a necessidade de remanejar recursos de outros setores e as novas necessidades evidenciadas com o processo de envolvimento com a vida comunitária, antes de serem entraves, podem ser oportunidades para discussão e aperfeiçoamento do novo modelo de assistência. Trata-se de uma modificação institucional que nasce não de um gerenciamento externo ou de um planejamento das instâncias hierarquicamente superiores da burocracia do sistema de saúde, e sim da transformação progressiva das competências existentes, das posturas profissionais, do reordenamento da utilização dos recursos disponíveis internamente e da superação do desânimo dos atores profissionais e populares envolvidos (Rotelli et al., 1990:36). Em virtude do curto espaço de tempo desta pesquisa, foi possível perceber muito mais os elementos potenciais desta dinâmica de transformação no Centro de Saúde Vila Leonina, do que a constatar resultados bem definidos. 


\section{Superar a tradição positivista dos serviços de saúde no manejo de grupos de risco}

A epidemiologia tem insistido que o risco de adoecer e morrer se distribui desigualmente na população. Há um movimento dos serviços de saúde no sentido de buscar identificar os grupos de maior risco para uma atuação mais dirigida, a fim de possibilitar maior eficácia e menor custo. A epidemiologia, refletindo o predomínio do positivismo nas ciências da saúde e, portanto, admitindo basicamente certezas testadas experimentalmente e validadas pelo raciocínio matemático, tem concentrado seus esforços buscando identificar características populacionais que estejam estatisticamente associadas ao maior risco de adoecer e morrer. São os chamados fatores de risco. Mendonça (1995), em estudo epidemiológico realizado em Belo Horizonte, mostrou que as mortes de crianças por diarréia, pneumonia e desnutrição tendem a ocorrer em famílias com os seguintes fatores de risco: precariedade das condições de moradia, instabilidade conjugal dos pais, baixo nível de escolaridade da mãe, ausência de acesso à rede pública de esgoto, filhos com baixo peso ao nascer, pequeno intervalo entre as gestações e presença de fumantes na residência.

O Projeto Vida, da Secretaria de Saúde de Belo Horizonte, refletindo essa tendência, vem procurando identificar e acompanhar (pela marcação de consulta médica e de atendimentos de enfermagem nos centros de saúde) os recém-nascidos (não as famílias) de risco através de variáveis já comprovadamente associadas, por métodos estatísticos, ao aumento da mortalidade em estudos epidemiológicos já realizados: baixo peso ao nascer, ser filho de mãe adolescente ou de mãe analfabeta. Apesar de significar um avanço, na medida em que reconhece a desigualdade do risco de adoecimento em uma população de determinada região aparentemente homogênea, esse projeto é ainda limitado por definir população de risco por fatores isolados e por centrar a priorização do apoio às crianças de risco em atividades de cunho individual (consultas médicas e atendimento de enfermagem) e apenas dentro do serviço de saúde, que se mostraram bastante ineficientes, nesta pesquisa, para esse grupo. As visitas domiciliares são utilizadas basicamente com a finalidade de trazer a criança e sua mãe para as atividades de atendimento dentro do Centro de Saúde. Além disso, uma mãe pode ser adolescente, analfabeta e, até mesmo, estar sem o apoio do pai da criança, mas se estiver morando em uma família bem articulada em que os avós, irmãos e vizinhos estejam intensamente envolvidos no cuidado da criança, o risco de adoecimento e morte será pequeno. A vida familiar é por demais complexa para poder ser classificada por meio de fatores de risco estanques. Muito mais importante do que a presença de alguns fatores de risco é a forma como eles se relacionam entre si e com os demais elementos da vida familiar e social local. A ênfase em buscar trabalhar com situações de risco padronizadas e definidas estatisticamente se correlaciona com o modelo de serviço que se quer construir. Em serviços operacionalizados por técnicos desqualificados e desmotivados (pelos baixos salários, por uma relação trabalhista autoritária e pela ausência de apoio educativo), atendendo de forma rotinizada e geridos, à distância, pela burocracia dos órgãos centrais de planejamento, a identificação das situações de risco por meio de características bem definidas e padronizadas é a forma possível de se atuar em larga escala e de modo uniforme. Tem se trazido para o processo de reorganização dos serviços de saúde o modelo e a ciência de administração do trabalho (o taylorismo e o fordismo) gestados na grande indústria capitalista na primeira metade do século (Vasconcelos, 1989) e hoje em profunda crise mesmo no mundo da produção.

Esse estudo mostrou a grande diferença de sensibilidade e acuidade na identificação de situações de risco entre o método padronizado preconizado pelo Projeto Vida e as visitas informais da equipe do programa de combate à desnutrição. Para um técnico treinado e motivado, as situações familiares de risco para a saúde se mostram nas mais diversas e surpreendentes formas de descuido que vão se evidenciando pela convivência e diálogo amigo. No próprio processo de identificação destas situações de risco já se inicia o apoio.

As visitas domiciliares são atividades que exigem grande disponibilidade de recursos humanos, inviabilizando a pretensão de se visitar toda a população sob responsabilidade de um serviço básico de saúde. É necessária, portanto, uma estratégia que selecione inicialmente as famílias com maior potencial de risco. Nesse sentido, a presença de crianças com desnutrição grave se mostrou um bom marcador de famílias em situação de risco, servindo como indicador inicial de famílias a serem visitadas. A identificação de crianças desnutridas, à medida que pode fazer parte da rotina das consultas pediátricas, é um procedimento facilmente operacionalizável em serviços de atenção pri- 
mária à saúde. Durante as reuniões com as mães de desnutridos, outras famílias não participantes iam sendo apontadas no debate. Algumas famílias foram indicadas pelas lideranças comunitárias participantes da Comissão Local de Saúde. O envolvimento dos vários profissionais do Centro de Saúde com a proposta do programa mostrou também ser muito importante na identificação das famílias em situação de risco, uma vez que eles, em seus atendimentos, têm um contato muito diversificado com a população. A miséria resulta em problemas de saúde que, mais cedo ou mais tarde, desembocam nos serviços locais de saúde. O olhar atento do profissional pode descobrir situações de negligência e abandono por trás de problemas pontuais de saúde. Mas a visita domiciliar mostrou ser o mais importante instrumento esclarecedor dessas situações.

Em 1992, 62\% das crianças com menos de um ano de idade, que morreram de diarréia e pneumonia em Belo Horizonte, eram desnutridas (Mendonça, 1995). Essas mortes, plenamente evitáveis com os recursos médicos atuais, confirmam a importância de se priorizarem as crianças desnutridas como grupo de risco merecedor de acompanhamento diferenciado. A significativa queda da freqüência de desnutridos na população em todas as regiões brasileiras, diminuindo o tamanho deste grupo de risco, vem tornando o seu acompanhamento mais fácil de ser operacionalizado. Entre 1975 e 1989, a prevalência de desnutrição global entre crianças menores de cinco anos no Brasil declinou de $18,4 \%$ para $7,1 \%$ (desnutrição definida pela relação peso para idade inferior a -2 desvios-padrão da mediana da população de referência do National Center of Health Statistics (Bittencourt \& Magalhães, 1995:280). Mesmo entre as crianças brasileiras menores de cinco anos pertencentes ao grupo de famílias mais pobres da população, a freqüência da desnutrição tem se reduzido: nesse grupo (primeiro quartil de renda familiar per capita), em 1989, 13,6\% tinham desnutrição global (Bittencourt \& Magalhães, 1995:282).

O programa de combate à desnutrição no C. S. Vila Leonina deixou de ter a recuperação nutricional como meta primeira para tornar-se uma estratégia global de saúde no Aglomerado Morro das Pedras, por intermédio da assistência diferenciada às famílias em situação de maior vulnerabilidade.

Mesmo a desnutrição sendo uma condição definida por características mensuráveis matematicamente (peso e idade) de acordo com padrões e classificações elaborados pela estatística, sua utilização como indicador de situações de risco não resultou numa abordagem positivista, já que foi utilizado como orientador inicial da seleção de famílias. A definição final das famílias acompanhadas foi feita por uma avaliação baseada em análise qualitativa da interrelação de diferentes fatores. O combate à desnutrição, assim como aos outros problemas utilizados como indicadores utilizados, não era o objetivo final do acompanhamento da equipe de saúde, e sim o ponto de partida para o entendimento e enfrentamento das repercussões da situação de miséria e opressão naquela população. Na avaliação das várias atividades executadas, desde as visitas até o tratamento de problemas específicos de saúde, a preocupação maior não era a quantidade de visitas, a porcentagem de curas de problemas específicos, o número de atividades computadas nos formulários preenchidos, o índice de incorporação de hábitos de higiene ensinados ou a freqüência com que ensinamentos sobre o ciclo das doenças foram aprendidos, mas sim o fortalecimento da capacidade daquelas famílias em lutar e buscar a saúde de seus membros.

\section{A priorização de dimensões culturais e subjetivas na luta pela saúde}

A aplicação e estudo da metodologia da educação popular num campo específico de intervenção institucional, comunitária e familiar, como é o caso do enfrentamento das doenças infecciosas e parasitárias, ganha sentido mais amplo no atual contexto de construção da democracia na América Latina, em que muitos buscam superar a separação entre a dinâmica de vida nas comunidades e na sociedade e o funcionamento das instituições públicas. Os caminhos da integração entre o formal e o informal estão sendo delineados, em grande parte, com base em experiências setorizadas. Como foi constatado nesta pesquisa, em práticas mais localizadas se torna mais clara a visualização de indicativos de solução dos gigantescos problemas sociais que marcam as classes populares, na medida em que se percebem suas sutis diferenciações e heterogeneidades, questionando-se, assim, a tradição de análise generalizante e estrutural predominante na sociologia médica. Dessa forma, tornam-se mais evidentes os pontos prioritários de atuação, contanto que se tome a precaução de não reduzir a abordagem desses problemas globais somente a ações localizadas.

Naquele ambiente marcado pela exclusão dos mais subalternos e onde os vários atores se encontram e interagem freqüentemente como 
estranhos, sem se compreenderem, a intervenção orientada pela metodologia da educação popular mostrou ser bastante útil na construção de novos conhecimentos e práticas solidárias de saúde que avançaram em direção à superação do descaso com os problemas de saúde dos pobres urbanos. Criou-se um ambiente de maior aproximação cultural entre vários profissionais de saúde e a população local. Mas uma aproximação parcial.

O esforço humano de construção do diálogo entre os diferentes personagens e grupos envolvidos nos problemas de saúde não é garantia de sucesso. O diálogo é falível; é uma realização humana parcial e provisória; não é nem garantido pela existência de boas intenções, nem tampouco impedido pela existência de sérias diferenças. Contudo, mesmo tentativas fracassadas de diálogo entre as diferenças podem nos ensinar algo: que a persistência não resolve todos os conflitos, que alguns problemas não são solucionáveis, mas apenas administráveis, e que um certo nível de mistério e perplexidade acompanha todos os esforços de compreensão humana. Dar-se conta desses elementos fortalece em nós uma saudável modéstia sobre as possibilidades e os limites de nossos esforços comunicativos (Burbules \& Rice, 1993).

Percebeu-se que as questões culturais são um elemento fundamental no funcionamento de um serviço local de saúde. Elas estão presentes na relação entre os diversos atores locais: moradores, organizações populares, diferentes grupos de profissionais, chefias locais e instâncias administrativas da Secretaria de Saúde. Tais questões culturais entravam ou potencializam as várias propostas em andamento. Uma reforma sanitária, que enfatize a renovação sócio-cultural e sócio-psíquica do cotidiano dos cidadãos e busque a construção de um sistema dinâmico e eficiente que atenda de modo integral os seus problemas de saúde, não pode depender de iniciativas educativas e comunicativas espontâneas e, portanto, freqüentemente transitórias de profissionais e movimentos sociais. É preciso que atividades educativas dentro da metodologia da educação popular sejam expandidas de forma sistemática nos serviços de saúde. A complexidade das práticas educativas e a necessidade de serem apoiadas por uma série de atividades, que preparem e criem condições prévias ao seu desenvolvimento, exigem profissionais qualificados com cargas horárias de trabalho significativas dedicadas às mesmas. Os caminhos institucionais para esta expansão não estão ainda claros, apesar da existência de algumas experiências municipais neste sentido. Uma consideração importante neste processo é que a habilitação para a dinamização de atividades de educação popular nos serviços de saúde não está concentrada em nenhuma categoria profissional específica; tem-se mostrado estar associada principalmente a uma vocação pessoal presente em diferentes tipos de profissionais, bem como a uma vivência anterior em projetos de educação popular integrados aos movimentos sociais. Uma vez que a forma de encaminhamento das atividades de educação popular em saúde depende das particularidades de cada lugar e de cada serviço, a estratégia mais adequada de expansão destas práticas passa muito mais pelo apoio material e educativo às iniciativas locais, do que pela difusão ampliada de projetos elaborados por especialistas para diversos serviços.

O progresso da assistência à saúde tem estado identificado principalmente com inovações tecnológicas: novos medicamentos, ressonância magnética, cirurgia laparoscópica, engenharia genética, transplantes, técnicas imunológicas de diagnóstico de alta sensibilidade e especificidade etc. Mas tão importante quanto esta evolução tecnológica é o avanço na definição de modelos de atenção à saúde que sejam, ao mesmo tempo, compatíveis com a realidade política, econômica e cultural da sociedade e das instituições onde se inserem e, ainda, contribuam para ampliar as condições de saúde de todos os cidadãos de uma forma que respeite sua autonomia e sua dignidade. No entanto, faz parte do senso comum a percepção de que esta construção institucional é algo que ocorre quase que naturalmente originada do trabalho rotineiro dos políticos e dos administradores. Muitos profissionais e amigos com quem convivi durante a pesquisa se surpreendiam com o interesse em estudar algo que não lhes parecia ser um problema importante da prática médica. Há um consenso de que é fundamental valorizar ações educativas e buscar uma maior aproximação da população, mas essas metas são vistas como dependentes apenas de maior empenho profissional e de valorização das lideranças institucionais. Usualmente não se percebe a imensa diversidade de possibilidades de encaminhamento dessas ações e nem mesmo as diferentes implicações e barreiras de cada uma delas. Não se percebe que não basta a existência de coerência técnica e administrativa numa proposta de reorganização da atenção à saúde se ela não for compatível com as características culturais, corporativas e econômicas dos atores envolvidos na sua implementação. Não se percebe o fazer educativo e 
o aperfeiçoamento da organização dos serviços de saúde como campo importante de pesquisa científica que exige a participação dos diferentes especialistas do setor. Numa sociedade regida de forma central pelo mercado, a pesquisa científica legitimada e valorizada é aquela associada à implementação do consumo de mercadorias.

Para uma grande parcela dos profissionais e administradores do setor saúde, o investimento em dimensões sócio-culturais e subjetivas é considerado supérfluo no contexto de carência material que marca a atenção à saúde das classes populares. Todavia, essa carência material existe numa sociedade que é também de abundância em razão da revolução do processo produtivo trazida pela industrialização. Carência e abundância convivem nas relações

\section{Referências}

BITTENCOURT, S. A. \& MAGALHÃES, R. F., 1995. Fome: um drama silencioso. In: Os Muitos Brasis; Saúde e População na Década de 80 (M. C. Minayo, org.), pp.269-290, São Paulo: Hucitec.

BRANDÃO, C. R., 1982. Lutar com a Palavra. Rio de Janeiro: Graal.

BURBULES, N. C. \& RICE, S., 1993. Diálogo entre as diferenças: continuando a conversação. In: Teoria Educacional Crítica em Tempos Pós-Modernos (T. T. Silva, org.), pp. 173-204, Porto Alegre: Artes Médicas.

CAMPBELL, H., 1993. Estudio etnográfico enfocado: instrumento de investigación sobre las IRA. Washington: Boletim do Grupo CID/OPS/OMS, no 24 , pp. 2-5.

COELHO, M., 1995. Estado trata a cultura como perfumaria. Folha de São Paulo, p. 9, caderno 5, 2 de junho.

FOUCAULT, M., 1985. Microfísica do Poder. Rio de Janeiro: Graal.

FREIRE, P., 1979. Pedagogia do Oprimido. Rio de Janeiro: Paz e Terra.

GERHARDT, H. P., 1996. Uma voz européia; arqueologia de um pensamento. In: Paulo Freire: Uma Biobibliografia (M. Gadotti, org.), pp.149-170, São Paulo: Cortez.

MAcDONALD, J. J. \& WARREN, W. G., 1991. Primary health care as an educational process: a model and a freirean perspective. International Quarterly of Community Health Education, 12:35-50.

MAURÁS, M. \& KAYAYAN, A., 1994. Apresentação. In: Família Brasileira, a Base de Tudo (S. M. Kaloustian, org.), pp. 9-10, São Paulo: Cortez.

MENDONÇA, E. F., 1995. Estudo de Determinantes da Mortalidade Infantil por Diarréia na Região Metropolitana de Belo Horizonte em 1991-1992. Tese sociais, justificadas e ordenadas pela cultura. A renovação dos padrões sócio-culturais e sóciopsíquicos que orientam a vida cotidiana é um elemento fundamental na superação da desigualdade de distribuição dos recursos materiais necessários ao enfrentamento da doença. Além do mais, saúde é muito mais que o provimento dos recursos materiais necessários, como nos mostra a mãe que, diante do filho acidentado, desdobra-se em consolá-lo e reconfortá-lo com o seu carinho enquanto o curativo dos ferimentos é realizado (Coelho, 1995). O investimento em dimensões culturais e subjetivas é elemento central na luta pela saúde. Precisa ser, portanto, assumido de forma explícita pelos serviços de saúde, estudando, preparando e difundindo palavras e gestos que acontecem nos atendimentos. de Doutorado, Belo Horizonte: Faculdade de Medicina, Universidade Federal de Minas Gerais.

MISOCZKY, M. C., 1994. A medicina de família, os ouvidos do príncipe e os compromissos do SUS. Saúde em Debate, 42:40-44.

NEDER, G., 1994. Ajustando o foco das lentes: um novo olhar sobre a organização das famílias no Brasil. In: Família Brasileira, a Base de Tudo (S. M. Kaloustian, org.), pp.26-46, São Paulo: Cortez.

NUNES, E., 1989. Carências urbanas, reivindicações sociais e valores democráticos. Lua Nova, 17:6791.

ROTELLI, F; LEONARDIS, O. \& MAURI, D., 1990. Desinstitucionalização, uma outra via; a reforma psiquiátrica italiana no contexto da Europa Ocidental e dos "países avançados". In: Desinstitucionalização (F. Rotelli, L. Ota, D. Mauri \& C. Risio, orgs.), pp.17-59, São Paulo: Hucitec.

TAKASHIMA, G. K., 1994. O desafio da política de atendimento à família: dar vida às leis - uma questão de postura. In: Família Brasileira, a Base de Tudo (S. M. Kaloustian, org.), pp.77-92, São Paulo: Cortez.

VALLA, V. V., 1993. A construção desigual do conhecimento e o controle social dos serviços públicos de educação e saúde. In: Participação Popular, Educação e Saúde: Teoria e Prática (V. V. Valla \& E. Stotz, orgs.), pp. 87-100, Rio de Janeiro: RelumeDumará.

VALLA, V. V., 1996. A crise de interpretação é nossa; procurando compreender a fala das classes subalternas. Educação e Realidade, 21/22:177-191.

VASCONCELOS, E. M., 1989. O taylorismo e a construção da medicina das classes populares. Serviço Social e Sociedade, 31:56-74. 